\title{
Комплексный анализ и прогноз развития эпидемиологической ситуации по COVID-19 в Российской Федерации
}

Антонец Д.В. ${ }^{1}$, Плоскирева А.А. ${ }^{2}$, Поспелов М.В. ${ }^{3}$, Смоленский В.Ю. ${ }^{4}$

${ }^{1}$ ФБУН ГНЦ ВБ «Вектор» Роспотребнадзора, Кольцово

2 ФБУН Центральный НИИ эпидемиологии Роспотребнадзора, Москва

${ }^{3}$ ФКУЗ РосНИПЧИ «Микроб» Роспотребнадзора, Саратов

${ }^{4}$ Федеральная служба по надзору в сфере защиты прав потребителей и благополучия человека, Москва

\section{Введение}

В декабре 2019 года ВОЗ получила уведомление о вспышке пневмонии неясной этиологии в г. Ухань (Китайская Народная Республика). Уже в начале января специалистам удалось выявить этиологический агент новой инфекции и его таксономическую принадлежность - возбудителем оказался ранее неизвестный представитель семейства Коронавирусов (Coronaviridae). Несмотря на беспрецедентные меры КНР по сдерживанию нового вируса к концу января случаи инфицирования были выявлены уже в 17 странах; в дальнейшем география распространения инфекции, в настоящее время именуемой COVID-19, активно расширялась. По состоянию на 22.08.2020 всего в мире зарегистрировано более 22,9 млн инфицированных новым вирусом, получившим название SARS-CoV-2, более 799 тысяч случаев закончились летальным исходом (по данным Центра системологии и инженерных наук Университета Джонса Хопкинса, далее - JHU). В настоящее время (22.08.2020) наибольшее количество случаев зафиксировано в США (5,62 млн), Бразилии (3,53 млн), Индии (2,98 млн), России (949 тыс.) и ЮАР (603 тыс.).

Цель: Проанализировать эпидемиологическую ситуацию по COVID-19 в Российской Федерации; представить на основании полученных данный прогноз вероятного развития эпидемии в Российской Федерации осенью 2020 г.

Краткая характеристика основных показателей эпидемического процесса в наиболее поражённых странах. На рис. 1 представлена динамика общего числа зарегистрированных случаев в странах с наибольшим числом заболевших (с общим числом зарегистрированных случаев COVID-19 $\geq 400$ тыс.). Показано сравнительное развитие ситуации - по оси абсцисс отложено количество дней, прошедшее с даты 
регистрации первой тысячи случаев. На рис. 2-6 показана сравнительная динамика числа активных случаев, заболеваемости, числа активных случаев на 100 тыс. населения, летальных исходов на 100 тыс. и изменение оценки уровня летальности (числа летальных исходов по отношению к общему числу зарегистрированных случаев COVID-19).

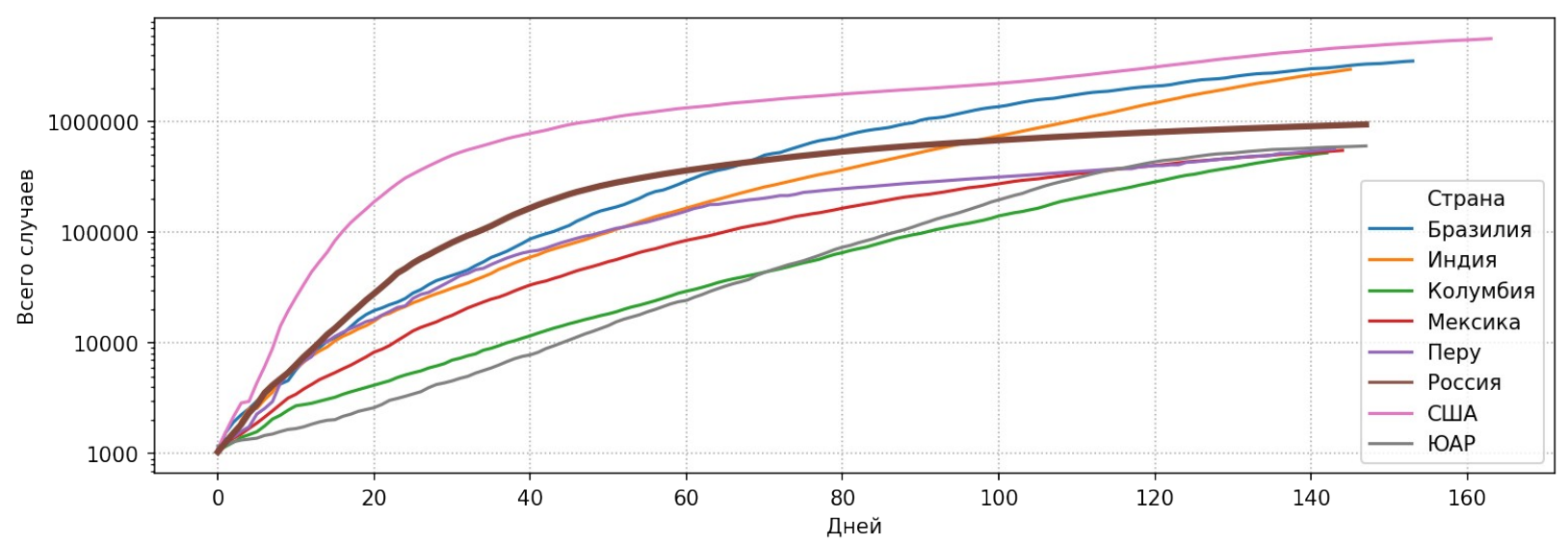

Рис. 1. Кумулятивное число случаев COVID-19 в странах с количеством зарегистрированных случаев более 400000 (США, Бразилия, Индия, Россия, ЮАР, Перу, Мексика, Колумбия). По оси абсцисс отложено количество дней от первой тысячи случаев (согласно данным JHU). По оси ординат использована логарифмическая шкала.

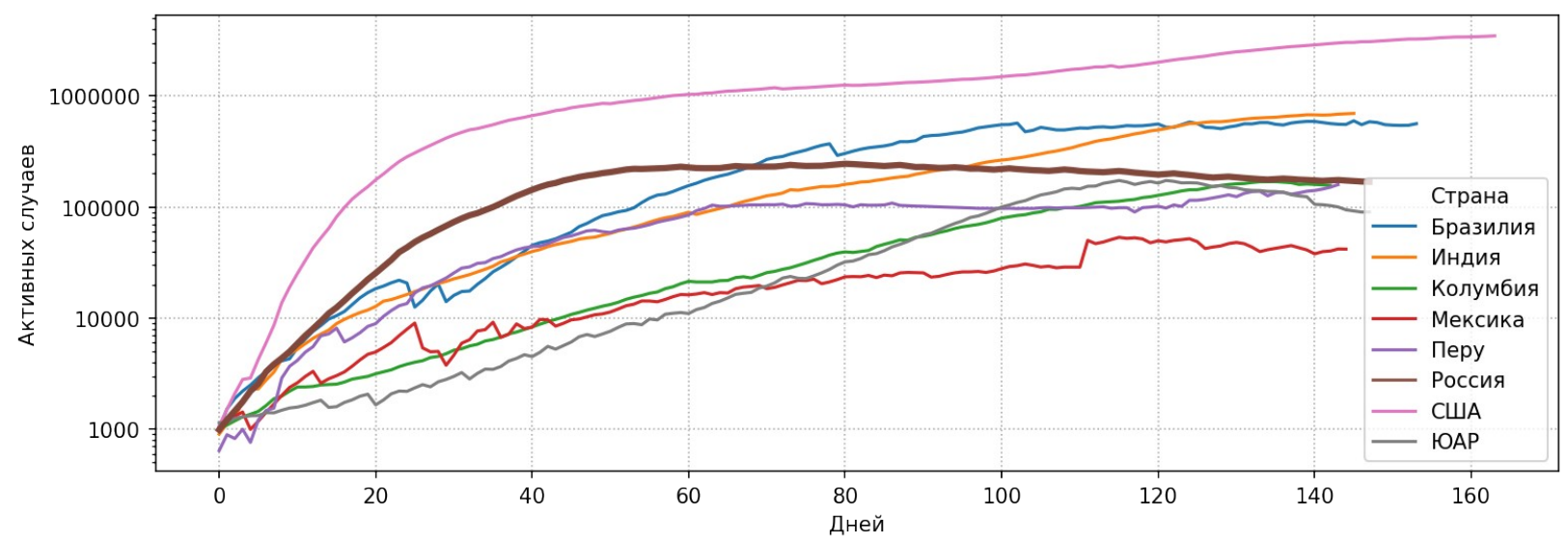

Рис. 2. Изменение числа активных случаев COVID-19 в странах с количеством зарегистрированных случаев более 400000 (США, Бразилия, Индия, Россия, Перу, ЮАР, Мексика, Колумбия). По оси абсцисс отложено количество дней от первой 1000 случаев (согласно данным JHU). По оси ординат использована логарифмическая шкала. 


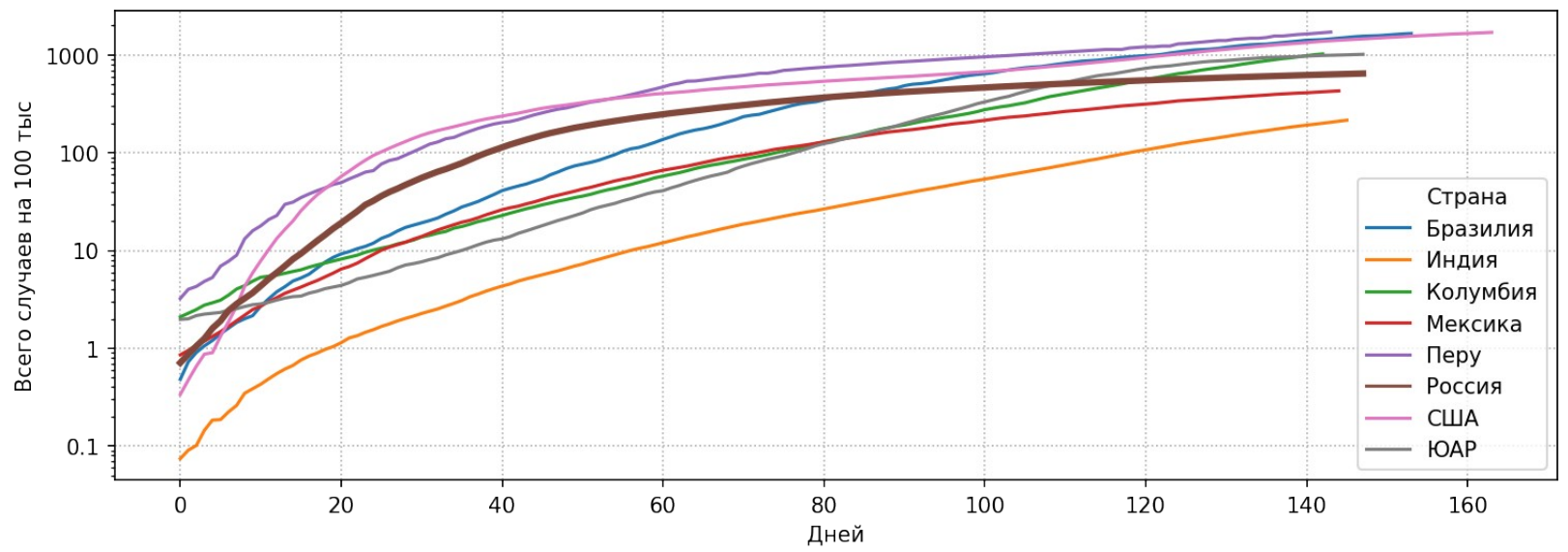

Рис. 3. Динамика количества случаев COVID-19 на 100 тысяч населения в странах с количеством зарегистрированных случаев более 400000 (США, Бразилия, Индия, Россия, Перу, ЮАР, Мексика, Колумбия). По оси абсцисс отложено количество дней от первой 1000 случаев (согласно данным JHU). По оси ординат использована логарифмическая шкала.

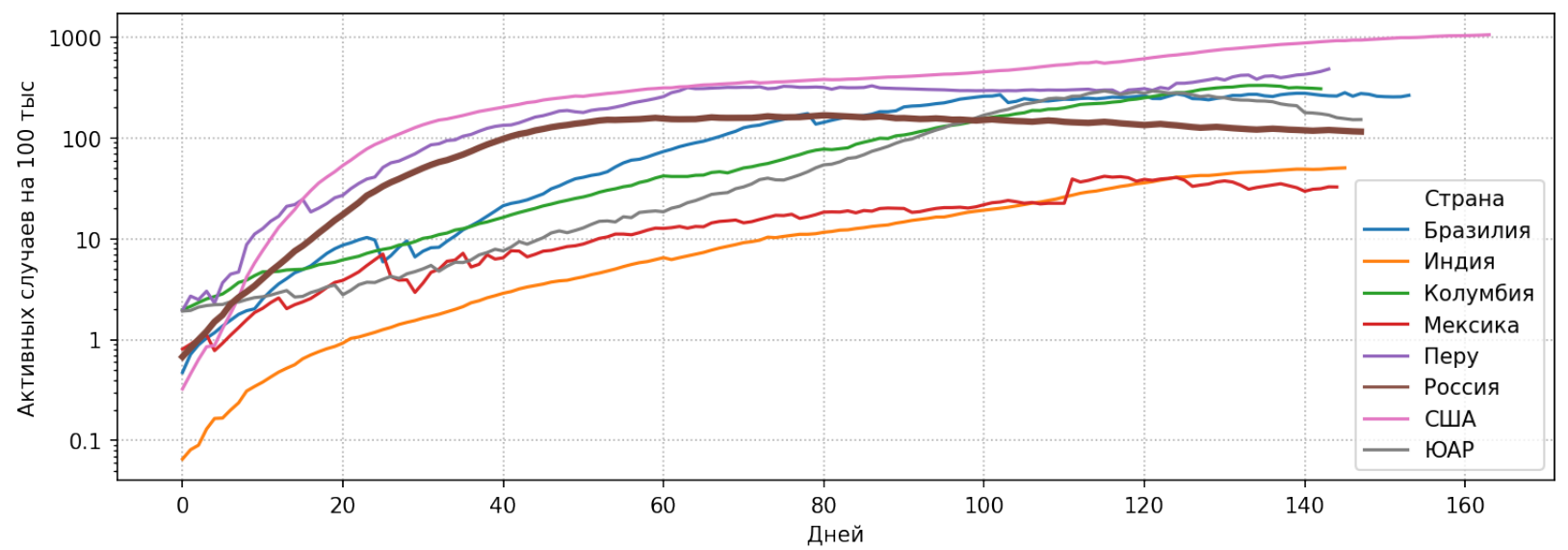

Рис. 4. Динамика количества активных случаев COVID-19 на 100 тысяч населения в странах с количеством зарегистрированных случаев более 400000 (США, Бразилия, Индия, Россия, Перу, ЮАР, Мексика, Колумбия). По оси абсцисс отложено количество дней от первой 1000 случаев (согласно данным JHU).

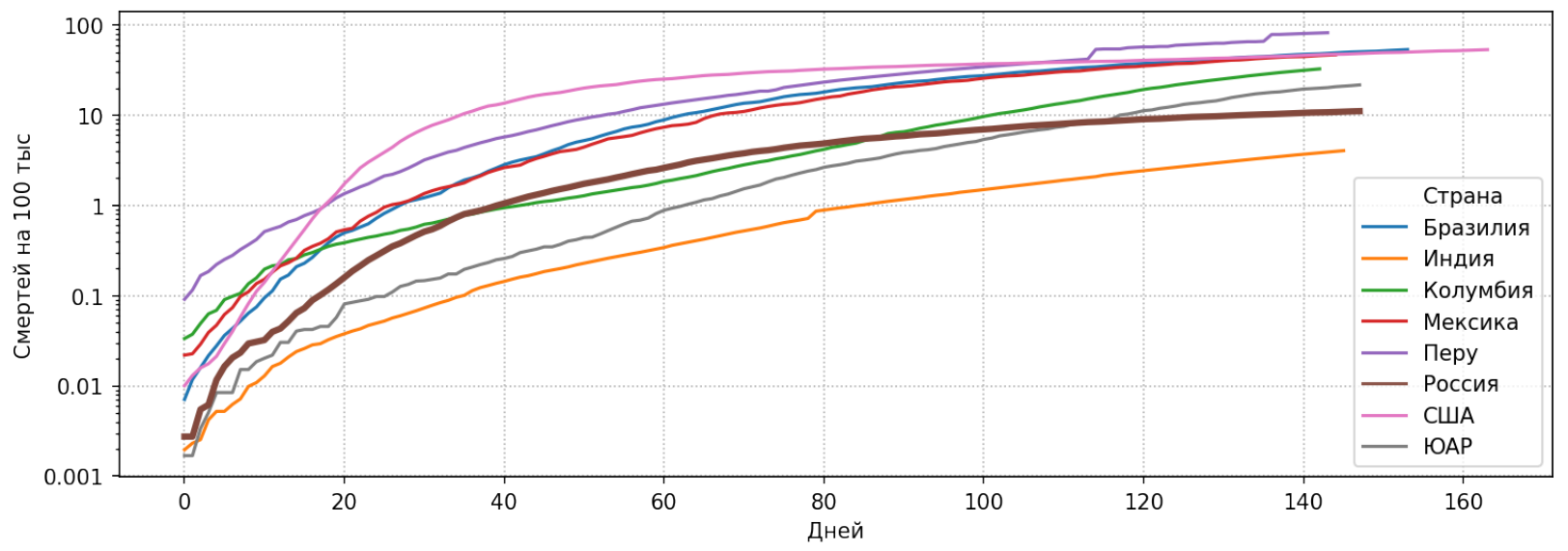

Рис. 5. Динамика числа летальных случаев на 100 тысяч населения в странах с количеством зарегистрированных случаев более 400000 (США, Бразилия, Индия, Россия, 
Перу, ЮАР, Мексика, Колумбия). По оси абсцисс отложено количество дней от первой 1000 случаев (согласно данным JHU).

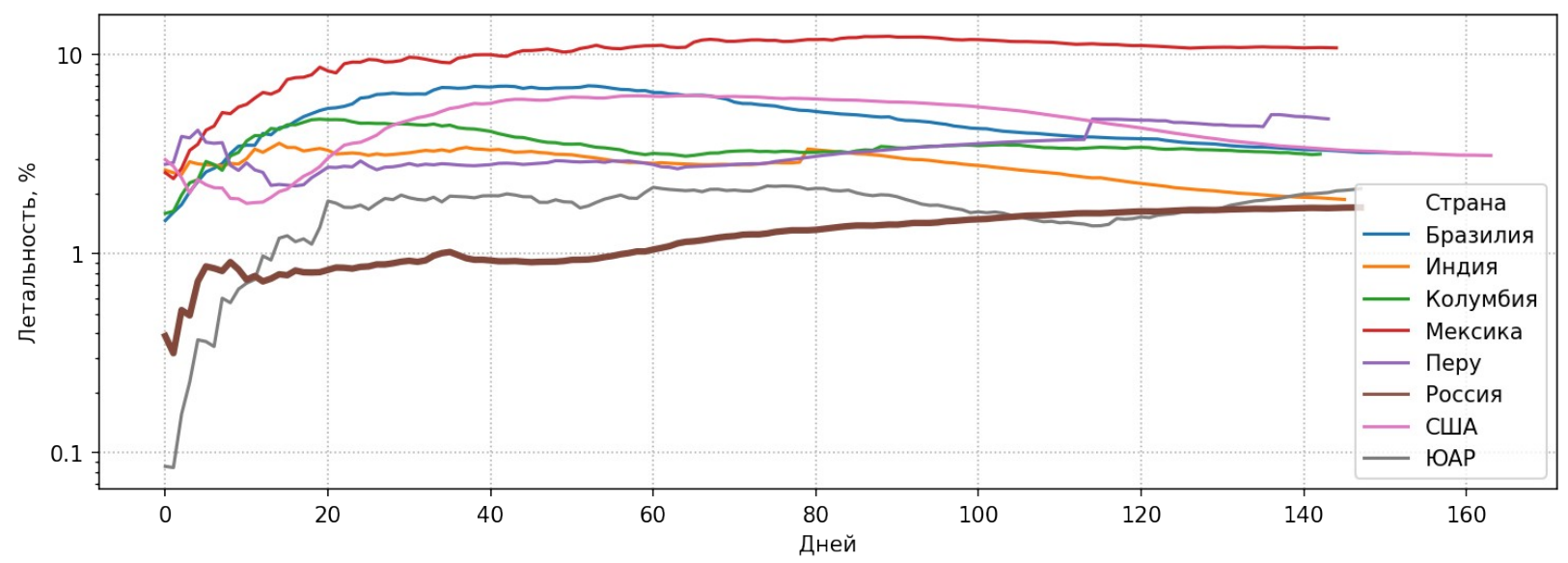

Рис. 6. Изменение летальности в странах с количеством зарегистрированных случаев более 400000 (США, Бразилия, Индия, Россия, Перу, ЮАР, Мексика, Колумбия). По оси абсцисс отложено количество дней от первой 1000 случаев (согласно данным JHU). По оси ординат использована логарифмическая шкала.

Показатели эпидемического процесса в Российской Федерации. В России на данный момент (22.08.2020) выявлено 951897 случаев заражения новым коронавирусом, из них - 168110 активных случая, 16310 - с летальным исходом. Около четырёх недель с момента выявления первого инфицированного в стране суточный прирост случаев составлял более 20-30\%, затем показатели суточного прироста снизились до значений менее 20\%. С начала мая темп прироста сократился до значений менее $10 \%$, что соответствует третьей фазе развития эпидемического процесса - завершению экспоненциального роста и переходу в линейный рост.

По состоянию на 09.08.2020 ежедневный прирост числа больных в Российской Федерации в целом составляет 0,52\%. Показатель летальности составляет 1,71\%. В 85 субъектах фиксируется суточный прирост менее 5\%, а в 83 субъектах - менее 2\%. Наиболее высокие показатели суточного прироста демонстрируют Республика Крым 2,96\%, Костромская область - 2,07\% и Республика Калмыкия - 1,92\%.

Плоскиревой А.А. (ЦНИИ Эпидемиологии) была предложена оригинальная методика ранжирования регионов по степени риска на пять групп:

1. Субъекты, где отмечаются темпы прироста более $30 \%$ на текущие сутки и в течение недели - гиперэкспоненциальный рост числа больных;

2. Субъекты, в которых отмечается превышение более $30 \%$ текущего показателя при средненедельном показателе менее 30\% - субъекты, угрожаемые по гиперэкспоненциальному росту;

3. Субъекты, в которых отмечается снижение темпов прироста на текущую дату, при этом средние темпы прироста в субъекте за неделю были более 30\%;

4. Субъекты, в которых темпы прироста (один или оба показателя) колеблются в пределах 10-29\%;

5. Субъекты, в которых темпы прироста меньше $10 \%$. 
На рис. 7 показано изменение распределения 85 субъектов Российской Федерации по степени риска по предложенной методике. Со второй декады мая ни один из регионов не был отнесен к III группе риска. На данный момент все регионы относятся к V группе.

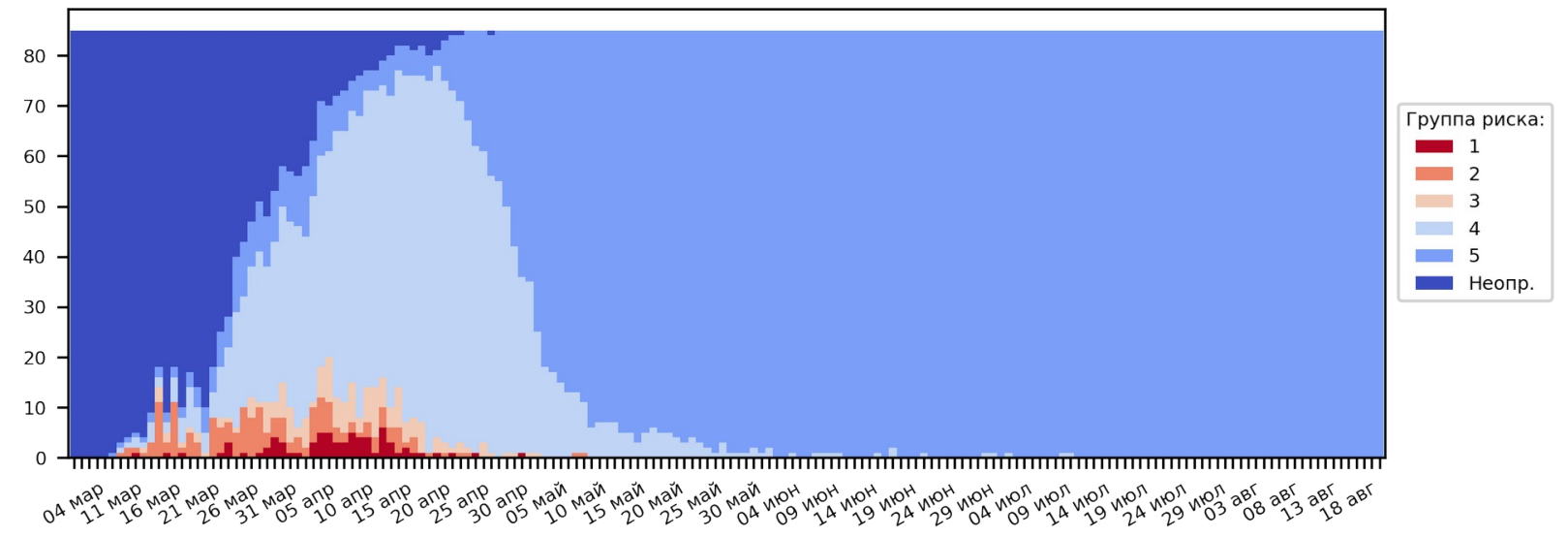

Рис. 7. Изменение распределения субъектов по группам риска.

Одним из наиболее важных показателей развития эпидемиологического процесса является базовое репродуктивное число $\left(\mathrm{R}_{0}\right)$ - среднее количество лиц, напрямую инфицированных больным при условии попадания его в полностью уязвимую (неиммунизированную) популяцию. Согласно литературным данным, значение $\mathrm{R}_{0}$ для COVID-19 составляет от 1,4 до 5,7 [1]. Согласно официальной оценке ВО3 - 2-4 [2].

Согласно результатам анализа развития эпидемии в Москве, проведенного нами с помощью SIR-модели [3], при оценке средней продолжительности инфекционного периода в 14 дней, в начале марта оценка базового репродуктивного числа $\mathrm{R}_{0}$ соответствовала 4,47. K концу марта эффективное репродуктивное число $\mathrm{R}_{\mathrm{e}}$ снизилось до 2,72-2,92; к концу апреля - ниже 1,3. 


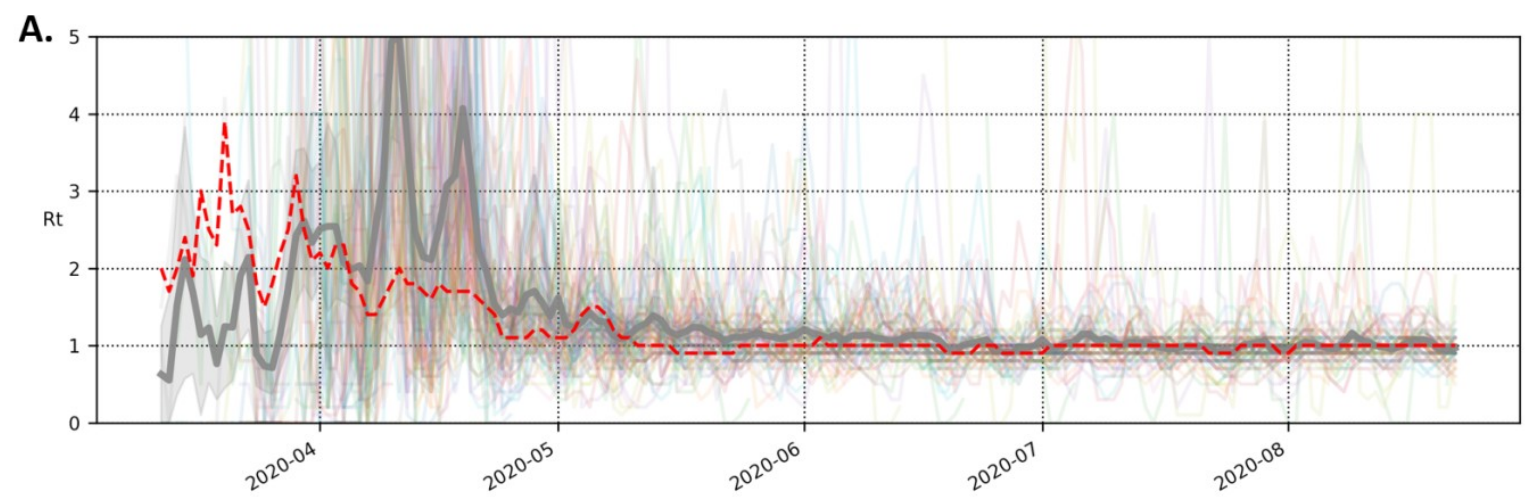

Б.

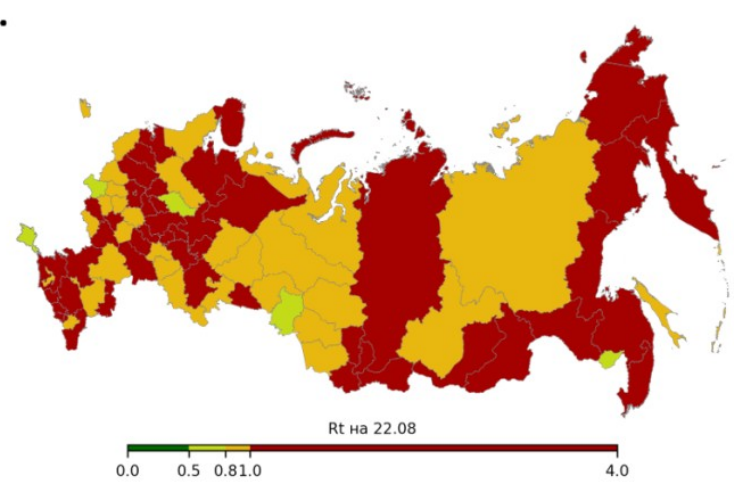

B.

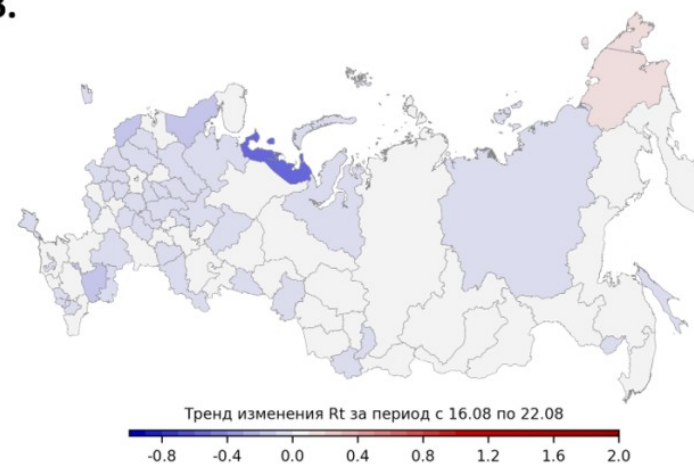

Рис. 8. Динамика изменения репродуктивного числа $R_{4}\left(R_{t}\right.$ за 4 дня). (A) изменение показателя $\mathrm{R}_{4}$, индивидуальные графики для регионов показаны разноцветными линиями, серым цветом показано среднее значение по регионам, красным - значение показателя для РФ; (Б) карта, отображающая диапазон значений $\mathrm{R}_{4}$ в регионах РФ; (В) тренд изменения показателя $\mathrm{R}_{4}$ за неделю.

На рис. 8А показано изменение репродуктивного числа Rt на интервале в 4 дня - R4. Видно, что оно снизилось с 4 в середине марта до 1 - в настоящее время. На рис. 8Б показано распределение значений показателя R4 по регионам. Видно, что на значительной части территорий данный показатель все еще больше 1, и следовательно, при неблагоприятном стечении обстоятельств рост заболеваемости может возобновиться. На рис. 8B видно, что во многих регионах уровень показателя R4 стабилизировался, в ряде регионов наблюдается тенденция к снижению, но в некоторых видна тенденция к росту.

B Российской Федерации на текущие сутки показатель R4 равен 1. B 14 субъектах показатель больше 1, в 37 - меньше 1, в 34 субъектах - равен 1. Наиболее высокий R4 отмечен в следующих регионах: Камчатский край $(1,9)$, Чукотский АО $(1,5)$ и КарачаевоЧеркесская Республика $(1,3)$. 

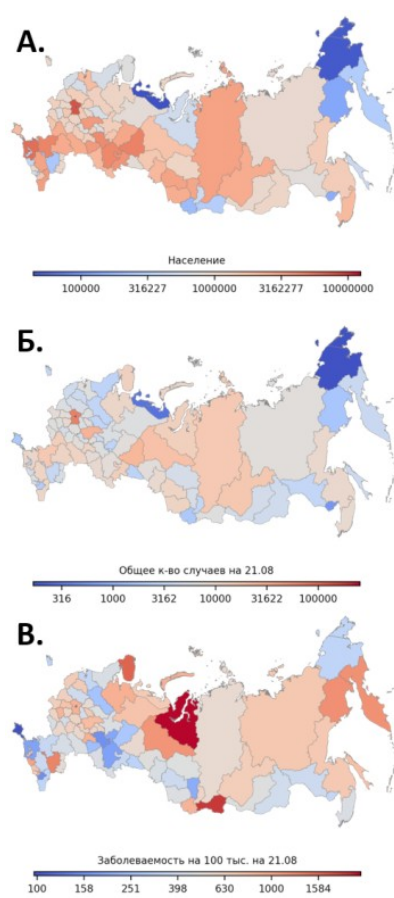
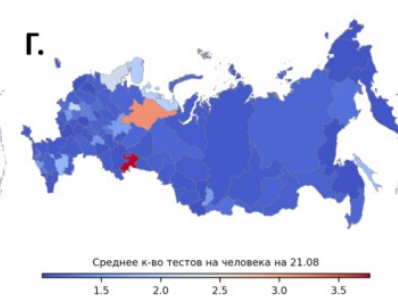

д.

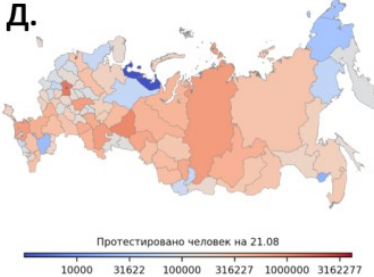

E.

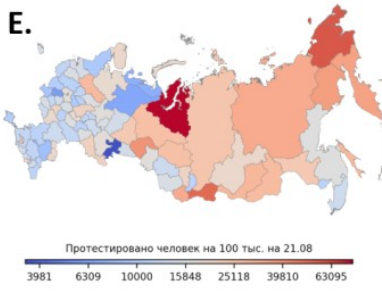

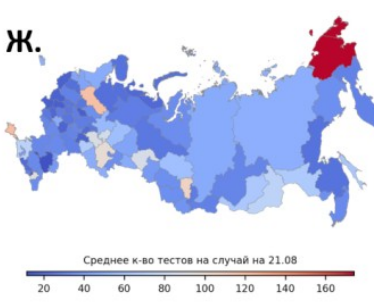

3.

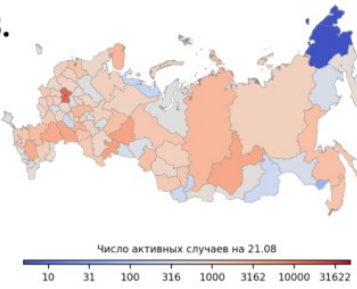

и.
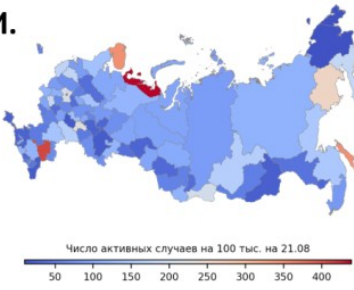
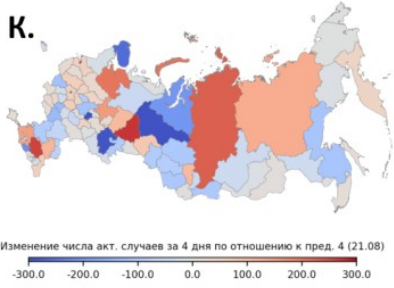

л.

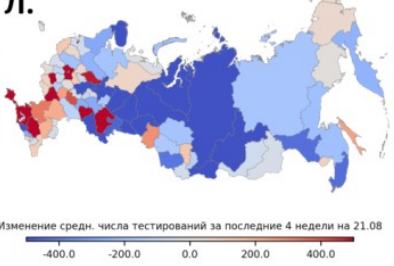

M.

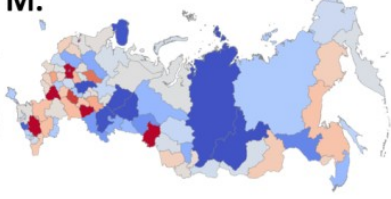

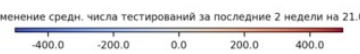

Рис. 9. Распределение ряда показателей по территории Российской Федерации. Отображены тепловые карты, показывающие численность населения в регионах (А), общее количество зарегистрированных случаев (Б), уровень заболеваемости на 100 тыс. населения (В), среднее количество тестов на человека (Г), общее количество протестированных (Д), количество протестированных на 100 тыс. (Е), среднее количество тестов на выявленный случай (Ж), число активных случаев (3), число активных случаев на 100 тыс. человек (И), изменение числа активных случаев за последние 4 дня по сравнению с предыдущими $4(\mathrm{~K})$, изменение среднесуточного числа тестирований за последние 4 недели (Л) и за последние 2 недели (М).

На рис. 9 продемонстрировано соответствие между численностью населения региона, количеством протестированных человек и количеством выявленных и активных случаев. В тоже время, стоит отметить слабое соответствие уровня заболеваемости (на 100 тыс.), числа протестированных на 100 тыс. Необходимо отметить, что регионы сильно отличаются по заболеваемости - от 97 до 2399 на 100 тысяч человек, межквартильный интервал - от 399 до 709 человек, в половине регионов уровень заболеваемости более 560 на 100 тысяч населения. В Москве, Московской области и Санкт-Петербурге заболеваемость составляет соответственно 2055, 894 и 655 случаев на 100 тысяч человек. Ряд показателей существенно отличается от региона к региону, так, по охвату населения тестированием максимальное значение (83758 тестов на 100 тыс. в ЯНАО) почти в 8 раз превышает минимальный показатель (10916 тестов на 100 тыс. в Брянской обл.); количество проведённых лабораторных исследований на один выявленный случай составляет от 12 (в Республике Калмыкия) до 174 тестов (в Чукотском АО). В настоящее время в 42 регионах наблюдается рост числа активных случаев (рис. 9К) - наибольший рост наблюдается в Санкт-Петербурге, Ставропольском крае, Свердловской области, Красноярском крае и Архангельской области, при этом в большинстве регионов (в 52 регионах) за последние 4 недели (с 24.07 по 21.08) произошло снижение среднесуточного количества тестирований (рис. 9Л). В 7 регионах уровень тестирования вырос за последние 2 недели (с 07.08 по 21.08) - в Алтайском и Забайкальском крае, Калужской и Ленинградской областях, в республиках Горный Алтай, Карелии, Марий Эл, Татарстане, 
Хакасия, в Саратовской и Тульской областях, Удмуртской Республике, Ульяновской области и Хабаровском крае. В 25 регионах уровень тестирования не сокращался (в Еврейской АО, Белгородской Брянской, Владимирской, Волгоградской, Воронежской и Костромской областях, Краснодарском крае, Курской, Магаданской, Московской, Новгородской, Омской, Орловской, Пензенской и Псковской областях, в Дагестане, Калмыкии, Республике Коми, Ростовской и Самарской областях, Санкт-Петербурге, Ставропольском крае, Тамбовской и Ярославской областях).

В значительной степени между регионами отличаются и показатели смертности от COVID-19 (рис. 10). По числу смертей на 100 тыс. населения лидируют Санкт-Петербург (43,52), Москва (37,85), Архангельская область $(21,59)$, Тульская область $(20,33)$, Республика Тыва $(18,74)$, Мурманская область $(17,60)$, Республика Калмыкия $(17,35)$, Ямало-Ненецкий АО (15,82), Республика Ингушетия $(15,69)$, Республика Дагестан $(15,66)$. Среднее количество смертей на 100 тыс. составляет 8,08, медиана - 5,88, межквартильный интервал - 3,49-11,01 на 100 тысяч.
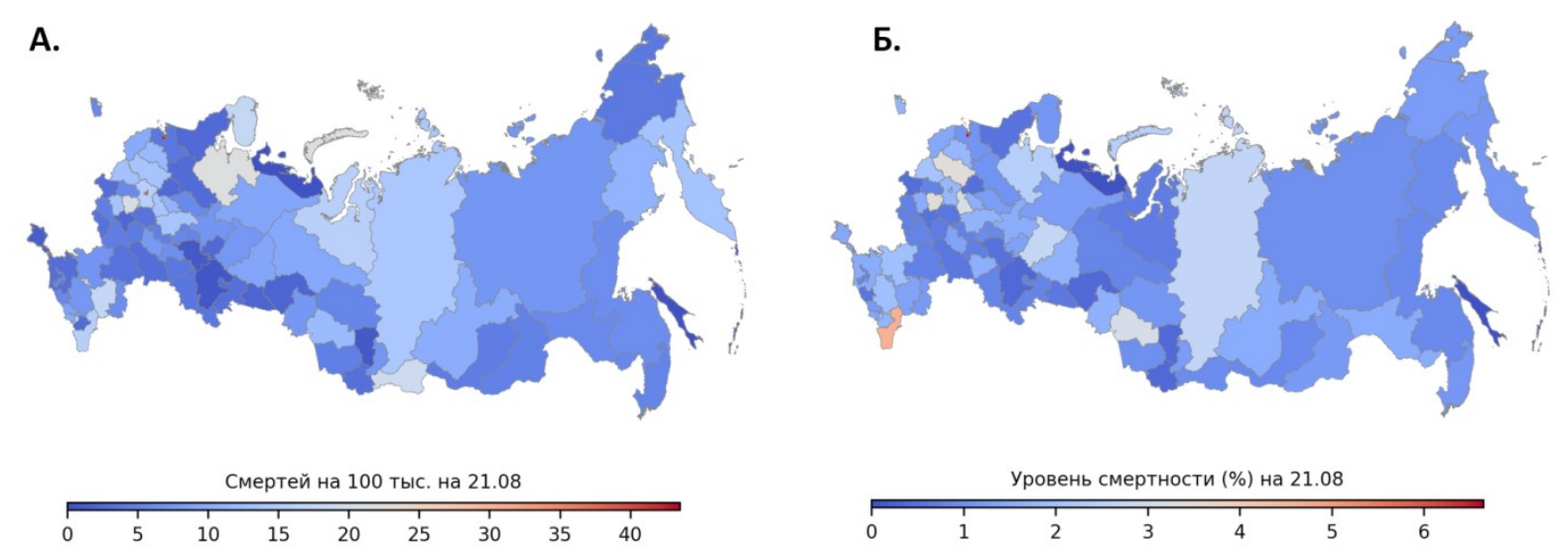

Рис. 10. Количество летальных исходов на 100 тыс. человек (А) и уровень смертности (Б) в регионах РФ.

Среднее значение летальности (на 21.08) составляет 1,34\%, медианный показатель 1,15\%, межквартильный интервал - 0,76-1,60\%. Наиболее высокая летальность отмечается в Санкт-Петербурге (6,64\%), Республике Дагестан (4,63\%), Тверской области (3,39\%), Тульской области (3,39\%), Владимирской области (3,15\%), Новосибирской области (3,08\%), Пермском крае (2,69\%), Красноярском крае (2,60\%), Архангельской области (2,38\%), Смоленской области (2,05\%). 


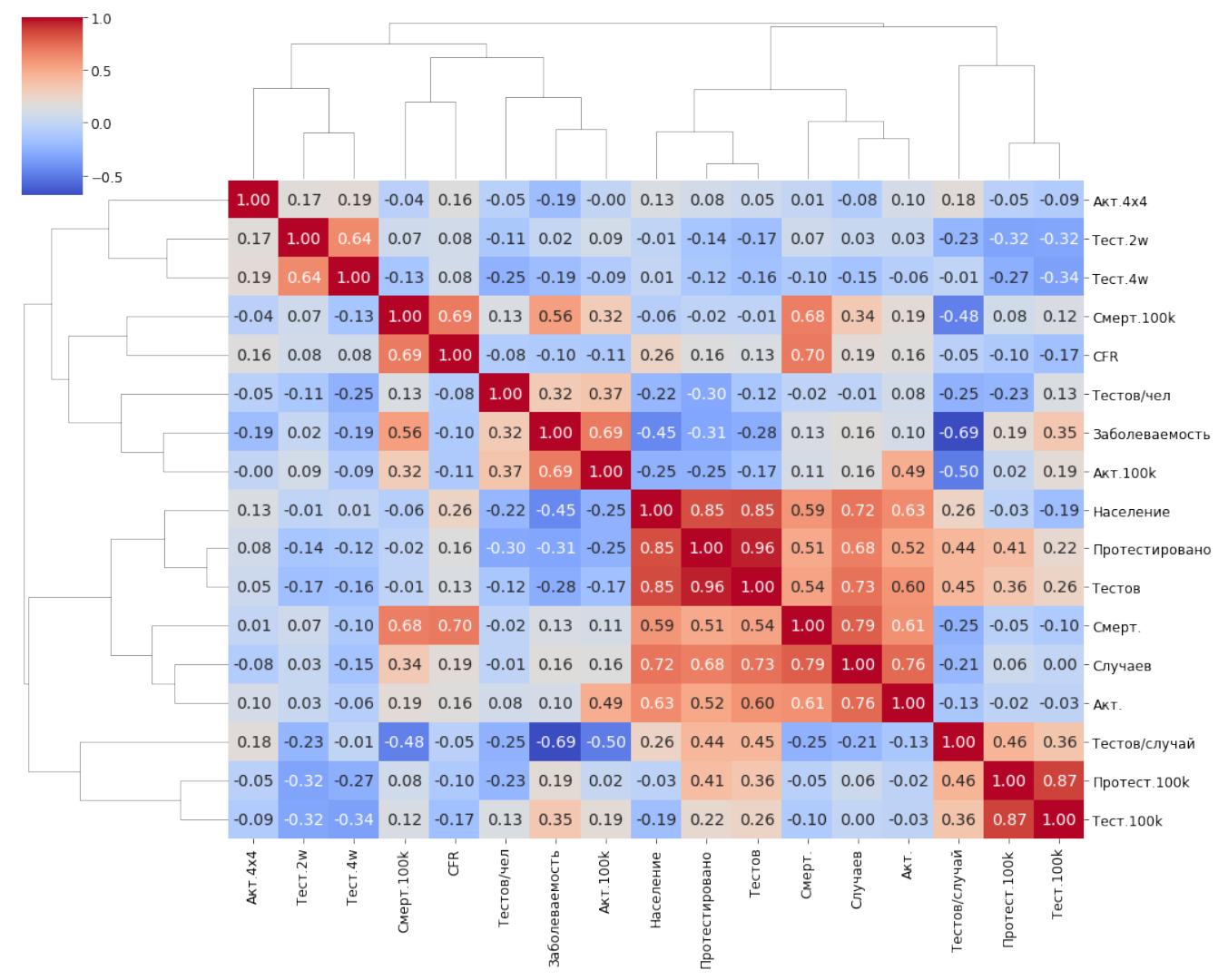

Рис. 11. Результаты корреляционного анализа. Красным цветом обозначена положительная корреляция, синим - отрицательная. В ячейках приведены значения коэффициентов корреляции Спирмена. Наиболее взаимосвязанные показатели сгруппированы вместе. Сравнивались следующие показатели: численность населения в регионах РФ (Население), количество протестированных пациентов (Протестировано), количество проведенных тестов (Тестов), количество летальных исходов (Смерт.), количество зарегистрированных случаев (Случаев), число активных случаев (Акт.), изменение числа активных случаев за последние 4 дня по сравнению с предыдущими 4 днями (Акт.4х4), изменение количества ежедневно проводимых тестов за последние 2 недели (Тест.2w), за последние 4 недели (Тест.4w), количество тестов на пациента (Тестов/чел), число летальных случаев на 100 тыс. населения (Смерт.100k), летальность (CFR), число случаев на 100 тыс. человек (Заболеваемость), число активных случаев на 100 тыс. (Акт.100k), количество тестов на случай (Тестов/случай), количество протестированных пациентов на 100 тыс. человек (Протест.100k) и количество тестов на 100 тыс. (Тест.100k).

В результате корреляционного анализа (Рис. 11) была обнаружена довольно сильная отрицательная корреляция между заболеваемостью и численностью населения $(-0,45)$, что может указывать на недостаточное тестирование в некоторых регионах. Сильная отрицательная корреляция наблюдается между количеством тестов на случай и заболеваемостью (-0,69), числом активных случаев на 100 тыс. человек $(-0,5)$ и числом летальных исходов на 100 тыс. $(-0,48)$. Наблюдается отрицательная корреляция между количеством тестов на случай и числом летальных исходов $(-0,25)$, числом зарегистрированных случаев COVID-19 $(-0,21)$ и числом активных случаев $(-0,13)$. На возможно недостаточную выявляемость указывает и тот факт, что при анализе выявлена уровня летальности и количества тестов на 100 тыс. человек выявлена слабая 
отрицательная корреляция $(-0,17)$. В частности, летальность в Москве составляет 1,84\%, в Санкт-Петербурге - 6,64\%. При этом уровень заболеваемости в Москве - 2056 на 100 тыс., в Санкт-Петербурге - 655. Количество тестов на 100 тыс. в Москве составляет 48155, а в Санкт-Петербурге - 39117.

Любопытно, что наблюдается слабая отрицательная корреляция между изменением среднесуточного числа лабораторных исследований за 4 недели и заболеваемостью ($0,19)$, количеством выявленных случаев $(-0,15)$ и количеством летальных исходов на 100 тыс. населения $(-0,13)$.

Проведенный анализ показал снижение числа лабораторных исследований во многих регионах РФ за последний месяц (Рис. 8Л, 12).

A.

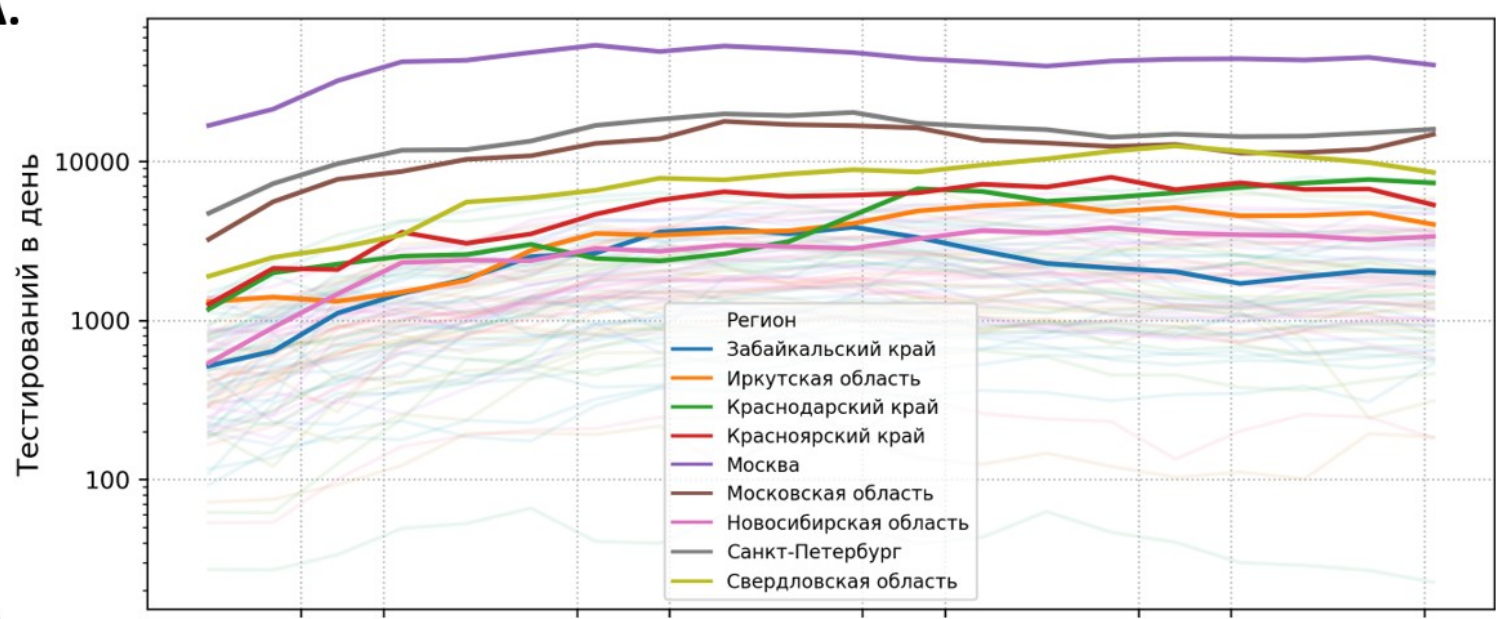

Б.

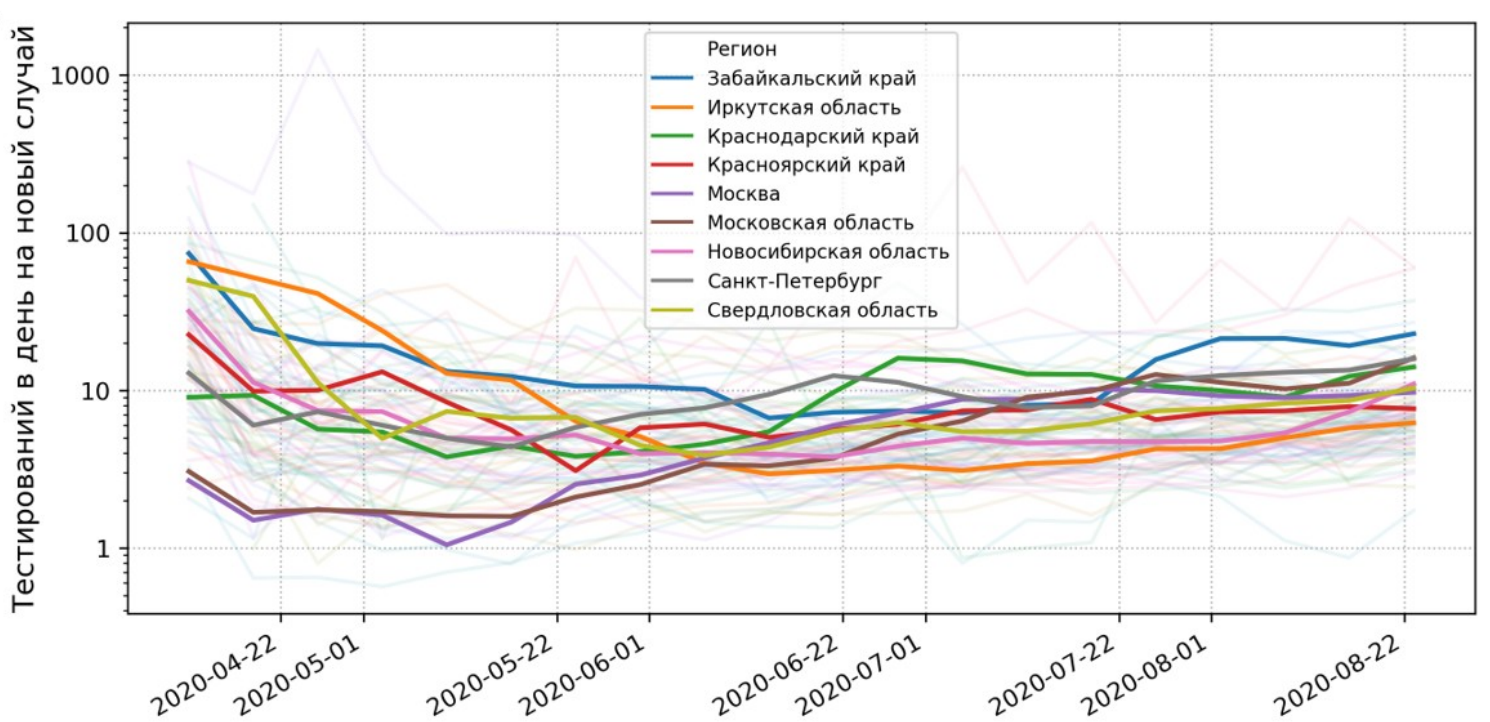

Рис. 12. Изменение числа тестирований в день в регионах РФ с апреля 2020 г. (А) Число тестирований в день - усреднено за неделю. (Б) Число тестирований в день на новый случай. Бледными линиями показаны графики для всех регионов, жирными линиями - для некоторых регионов РФ.

Таким образом, можно предположить, что недостаточное тестирование и снижение темпов тестирования может оказывать влияние на динамику прироста активных случаев. 
Важным показателем является количество активных случаев. Графики, отражающие динамку количества активных случаев COVID-19, представлены на рис. 13. В ряде регионов число активных случаев заметно растет за последние недели, в частности, в Санкт-Петербурге, Краснодарском крае, Красноярском крае и др.

A.

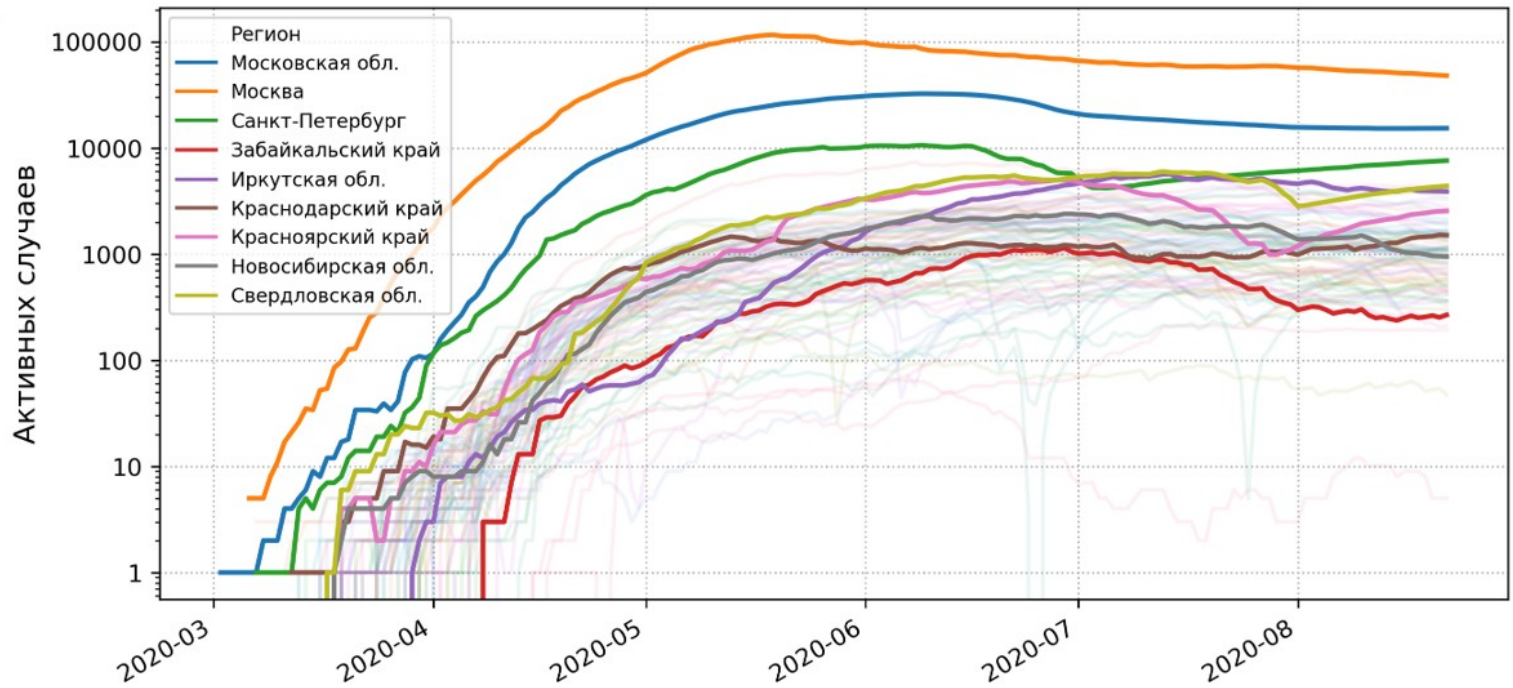

Б.

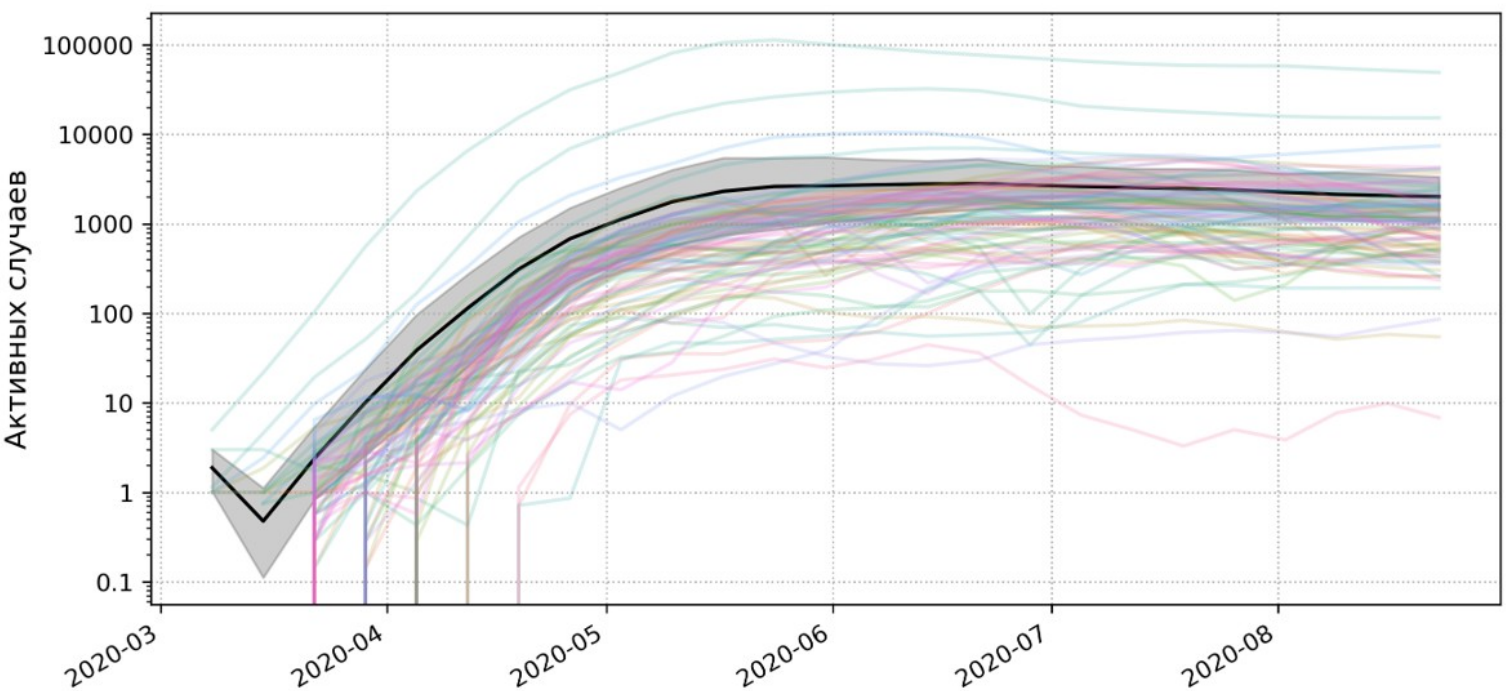

Рис. 13. Изменение числа активных случаев в регионах РФ с марта 2020 г. (А) Число активных случаев для всех регионов РФ показано бледными линиями, жирными линиями - для указанных регионов. (Б) Число активных случаев усреднено за неделю. Черная линия показывает динамику среднего значения количества активных случаев.

По числу активных случаев лидируют Москва и Московская область - 48389 и 15338 случаев, соответственно, Санкт-Петербург - 7537 случаев, Свердловская область (4326), Челябинская область (4235), Саратовская область (4026), Иркутская область (3904), Волгоградская область (3560), Ставропольский край (3343) и Ульяновская область (2842). Среднее число активных случаев - 2016, межквартильный интервал - от 529 до 1610. В половине регионов число активных случаев выше 1053. Среднее число активных случаев на 100 тыс. населения - 108, межквартильный интервал - от 51 до 125, медиана - 88 случаев, минимальное (Чукотский АО) - 10 случаев на 100 тыс. По числу активных случаев на 100 тыс. населения лидируют Ненецкий АО (438,97), Республика Калмыкия $(407,44)$, Москва $(388,87)$, Мурманская область $(348,34)$, Сахалинская область $(345,16)$, 
Магаданская область $(256,16)$, Ульяновская область $(227,41)$, Московская область $(205,51)$, Республика Тыва $(203,04)$ и Орловская область $(186,01)$. Максимальное и минимальное число активных случаев на 100 тыс. населения отличаются более чем в 43 раза.

За последние дни наибольшее сокращение числа активных случаев отмечено в Москве, Чувашии, Ханты-Мансийском АО, Башкортостане, Мурманской области, КарачаевоЧеркессии, ЯНАО, Воронежской, Липецкой и Смоленской областях. Наибольший рост отмечается в Санкт-Петербурге, Ставропольском крае, Свердловской области, Красноярском крае, Архангельской и Кировской областях, Краснодарском крае, Якутии, Кемеровской области и Пермском крае. Увеличение числа активных случаев наблюдается в 42 регионах.

Стоит отметить, что минимальные и максимальные цифры заболеваемости на 100 тыс. между регионами отличается почти в 30 раз, минимальное и максимальное количество протестированных индивидуумов на 100 тыс. человек между регионами отличается в 21 раз. Все это указывает на то, что для сравнения регионов не стоит полагаться на абсолютные показатели без нормировки на численность населения, охват тестированием и Т.П.

Одним из важнейших факторов, сдерживающих рост эпидемии, является ограничение контактов. Компанией «Яндекс» был предложен такой показатель, как «Индекс самоизоляции», отражающий уровень городской активности в данный момент и в обычный день до эпидемии. Чем ниже значение индекса, тем больше людей на улицах. Наиболее высокое значение индекса - 5 баллов. Значения в диапазоне 0-2,4 баллов - на улице очень много людей, 2,5-2,9 баллов - на улице много людей, 3-3,5 балла - на улице есть люди, 3,6-3,9 - большинство людей находится дома. На рис. 14 показана динамика изменения индекса самоизоляции в 100 наиболее населённых городах России. Активность горожан с середины лета стремится к значениям, характерным для начала эпидемии в стране, когда отсутствовали строгие рекомендации по домашней изоляции для населения. С наступлением осени активность населения, скорее всего, возрастёт.

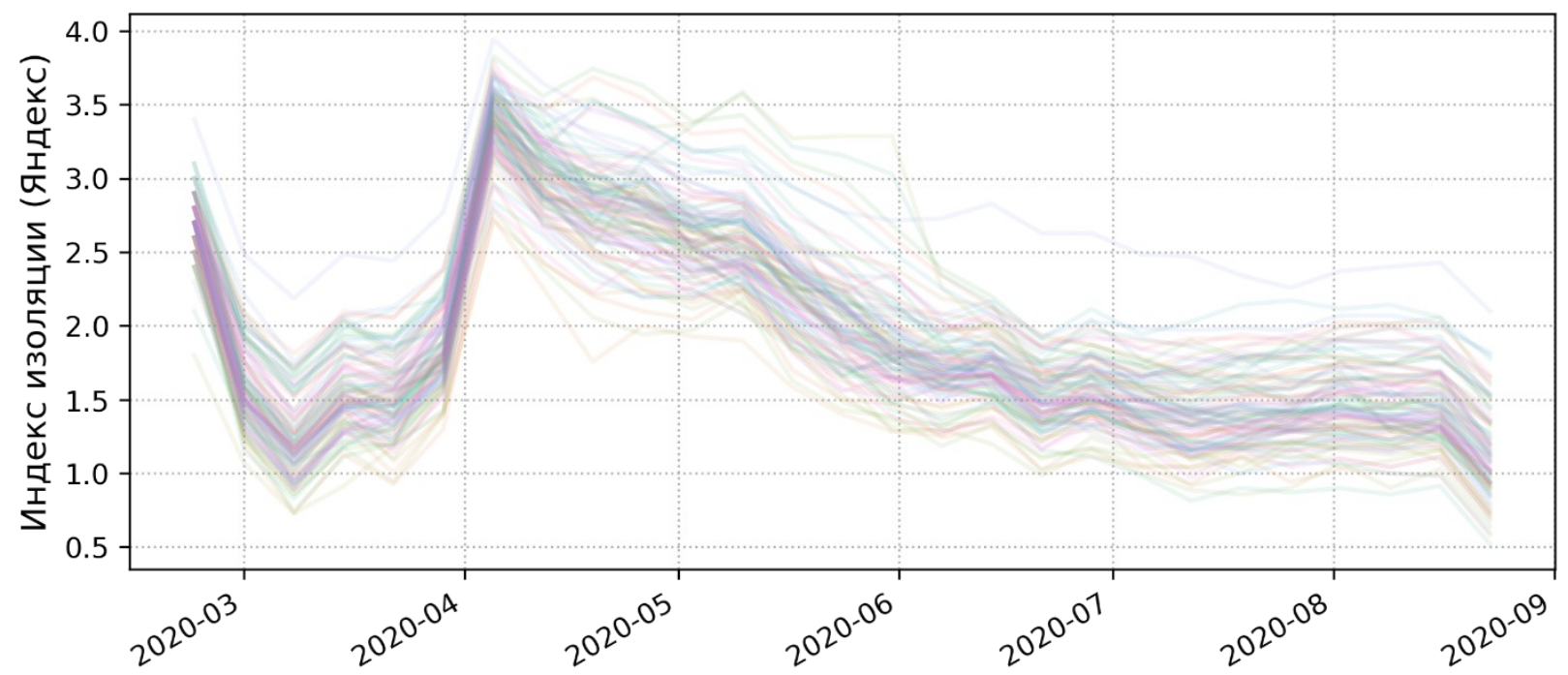

Рис. 14. Изменение индекса самоизоляции (по данным Яндекс) в 100 наиболее крупных городах РФ. Среднесуточные ежедневные значения, усредненные за неделю. 
Прогноз развития ситуации на осень 2020 г. На фоне увеличения деловой активности, сокращения числа граждан, соблюдающих режим самоизоляции, снятия ограничений на работу предприятий общепита, торговли и т.п., начала учебного года и окончания периода отпусков в России возможна вторая волна эпидемии COVID-19. Прогнозирование ситуации на осень-зиму текущего года является сложной задачей и вряд ли может быть выполнено с высокой точностью, тем не менее можно дать некоторую оценку ситуации. Прогноз основан на анализе фаз развития эпидемии и предполагает оптимистичный, медианный и пессимистичный варианты интенсивности и длительности фаз развития эпидемии в Российской Федерации.

Расчет прогноза числа инфицированных новой коронавирусной инфекцией COVID-19 осуществлялся с использованием актуальных данных о количестве выявленных случаев заболевания новой коронавирусной инфекцией и летальных исходов в Российской Федерации. Показатель прироста рассчитан как отношение разницы кумулятивного числа больных на текущий и предыдущий день к общему числу больных на предыдущий день. Оригинальная методика предложена Плоскиревой А.А. (ЦНИИ Эпидемиологии). Данная методика используется для регулярной подготовки краткосрочных прогнозов. В Российской Федерации в настоящее время наблюдается устойчивое снижение темпов ежедневного прироста числа больных, с 03.05 темпы прироста стабильно меньше 10\%, что соответствует третьей фазе развития эпидемического процесса - завершение экспоненциального роста и переход в линейный рост. На сегодняшний день темп прироста составляет 0,52\%, средний уровень летальности составляет 1,71\%. Оригинальная методика была модифицирована - для каждого региона уровень смертности оценивается на основе последних актуальных данных; темп прироста для оптимистичного сценария определяется на основе анализа линейного тренда числа новых случаев за выбранный интервал времени (по умолчанию - 2 недели); методика расчета негативного сценария не изменялась. Подробное описание методики приведено в разделе материалы и методы.

Исходя из этих данных проведен долгосрочный прогноз развития ситуации - до конца осени 2020 г. Смоделировано 2 сценария:

1. Оптимистичный (подразумевается продолжение тренда на снижение темпов прироста);

2. Негативный (повышение темпов прироста к показателям, характерным для 2 фазы эпидемии, например, за счет роста числа новых случаев в субъектах Российской Федерации) - второй волны эпидемии. Негативный сценарий моделируется на основе оптимистичного, в качестве условной даты начала второй волны нами принято 14 сентября 2020 г.

Результаты моделирования представлены на рис. 15. Согласно полученной модели при реализации оптимистичного сценария по состоянию на 30.11.2020 г. ожидается около 1340 тысяч случаев инфицирования, из них около 267 тыс. тяжелых и примерно 23 тыс. летальных, согласно пессимистичному сценарию будет зарегистрировано более 1632 тысяч случаев заболевания, из них более 345 тыс. тяжелых и более 27 тыс. летальных. 
A.

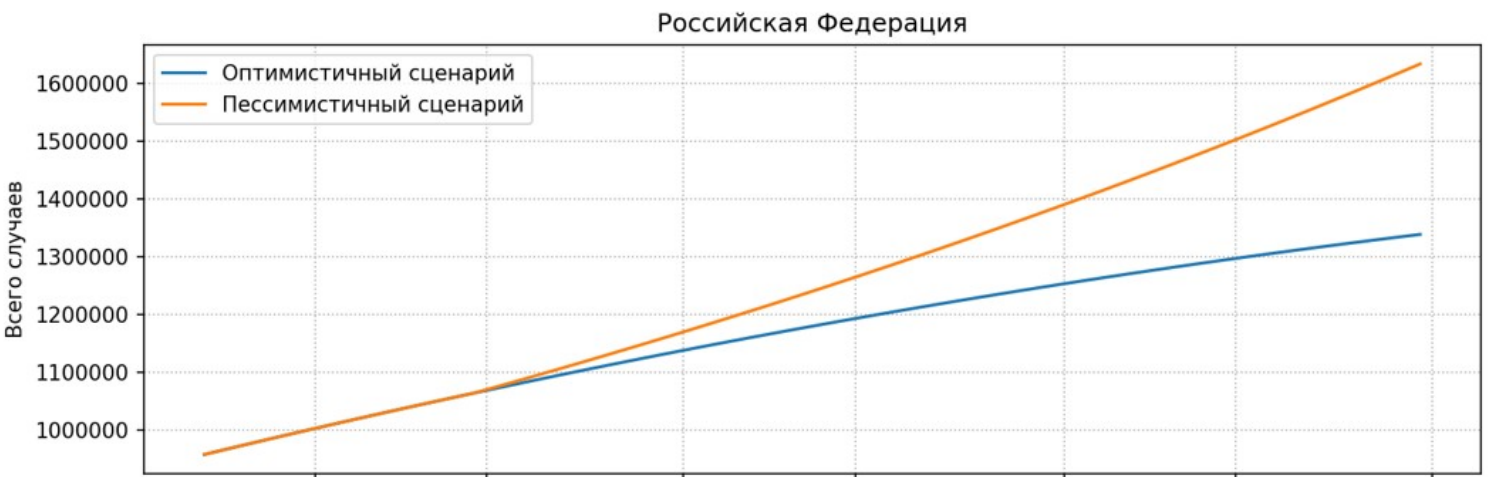

Б.

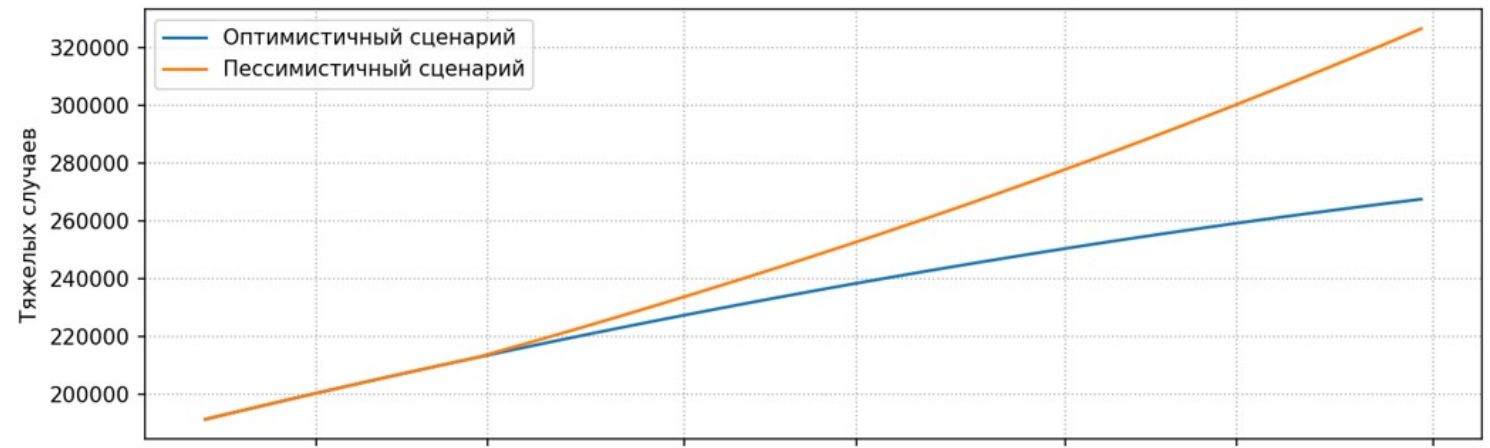

B.

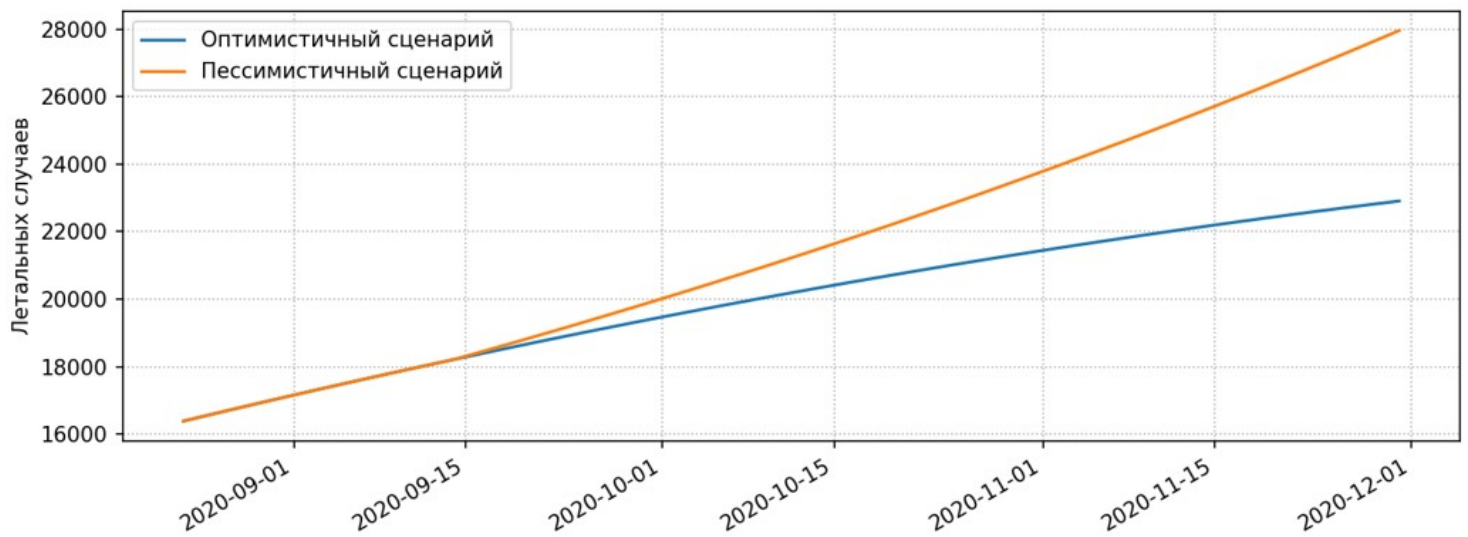

Рис. 15. Прогноз развития эпидемии COVID-19 в Российской Федерации до 30.11 .2020 г. Показано расчётное общее количество случаев (А), количество тяжелых (Б) и количество летальных случаев (В). Показаны результаты оптимистичного (синяя линия) и пессимистичного прогноза (оранжевая линия).

\section{Выводы}

В Российской Федерации в настоящее время наблюдается устойчивое снижение темпов ежедневного прироста числа инфицированных. С начала мая темп прироста сократился до значений менее $10 \%$, что соответствует третьей фазе развития эпидемического процесса завершению экспоненциального роста и переходу в линейный рост. На сегодняшний день (22.08.2020) темп прироста составляет $0,52 \%$, средний уровень летальности составляет $1,71 \%$. Во всех регионах Российской Федерации значение суточного прироста упало ниже $4 \%$, д для подавляющего большинства регионов - ниже $2 \%$. 
Репродуктивное число $\mathrm{R}_{\mathrm{t}}$, рассчитанное для интервала в 4 дня, $-\mathrm{R}_{4}-$ снизилось с 4 в середине марта до 1 в настоящее время. Однако во многих регионах данный показатель все еще не меньше 1, а значит сохраняется потенциал для роста заболеваемости.

Регионы сильно отличаются по уровню заболеваемости - от 97 до 2399 на 100 тысяч человек, межквартильный интервал - от 399 до 709 человек, в половине регионов уровень заболеваемости более 560 на 100 тысяч населения. В Москве, Московской области и Санкт-Петербурге заболеваемость составляет соответственно 2055, 894 и 655 случаев на 100 тысяч человек. тестированием максимальное значение (83758 тестов на 100 тыс. в ЯНАО) почти в 8 раз превышает минимальный показатель (10916 тестов на 100 тыс. в Брянской обл.); количество проведённых лабораторных исследований на один выявленный случай составляет от 12 (в Республике Калмыкия) до 174 тестов (в Чукотском AО). В значительной степени между регионами отличаются и показатели смертности от COVID-19. По числу смертей на 100 тыс. населения лидируют Санкт-Петербург $(43,52)$ и Москва $(37,85)$. Среднее количество смертей на 100 тыс. составляет 8,08, медиана - 5,88, межквартильный интервал - 3,49-11,01 на 100 тысяч. Среднее значение летальности (на 21.08 ) составляет $1,34 \%$, медианный показатель - 1,15\%, межквартильный интервал 0,76-1,60\%. Наиболее высокая летальность отмечается в Санкт-Петербурге (6,64\%).

В результате корреляционного анализа была обнаружена довольно сильная отрицательная корреляция между заболеваемостью и численностью населения (коэффициент корреляции Спирмена равен -0,45), что может указывать на недостаточное тестирование в некоторых регионах. Сильная отрицательная корреляция наблюдается между количеством тестов на один выявленный случай и заболеваемостью $(-0,69)$, числом активных случаев на 100 тыс. человек $(-0,5)$ и числом летальных исходов на 100 тыс. (0,48). Наблюдается антикорреляция между количеством тестов на случай и числом летальных исходов $(-0,25)$, числом зарегистрированных случаев COVID-19 $(-0,21)$ и числом активных случаев $(-0,13)$. На возможно недостаточную выявляемость указывает и тот факт, что при анализе уровня летальности и количества тестов на 100 тыс. человек выявлена слабая отрицательная корреляция $(-0,17)$. Любопытно, что наблюдается слабая антикорреляция между изменением среднесуточного числа лабораторных исследований за 4 недели и заболеваемостью $(-0,19)$, количеством выявленных случаев $(-0,15)$ и количеством летальных исходов на 100 тыс. населения $(-0,13)$.

Все это указывает на то, что сравнение регионов нужно проводить с большой осторожностью и что абсолютные показатели не могут использоваться без нормировки на численность населения, охват тестированием и т.п.

В настоящее время в 42 регионах наблюдается рост числа активных случаев наибольший рост наблюдается в Санкт-Петербурге, Ставропольском крае, Свердловской области, Красноярском крае и Архангельской области, при этом в большинстве регионов (в 52 регионах) за последние 4 недели (с 24.07 по 21.08) произошло снижение среднесуточного количества тестирований. Лишь в 25 регионах уровень тестирования не сокращался (в Еврейской АО, Белгородской Брянской, Владимирской, Волгоградской, Воронежской и Костромской областях, Краснодарском крае, Курской, Магаданской, Московской, Новгородской, Омской, Орловской, Пензенской и Псковской областях, в Дагестане, Калмыкии, Республике Коми, Ростовской и Самарской областях, СанктПетербурге, Ставропольском крае, Тамбовской и Ярославской областях). 
Таким образом, можно предположить, что недостаточное тестирование и снижение темпов тестирования может оказывать влияние на прирост активных случаев и демонстрировать искажённую картину замедления эпидемии.

Анализ показателей активности населения - в частности, динамика изменения «индекса самоизоляции», предложенного компанией Яндекс, показывает, что активность горожан возвращается к значениям, характерным до начала эпидемии. С наступлением осени активность населения, скорее всего, вернется к уровню, соответствующему аналогичному периоду прошлого года. На фоне увеличения деловой активности, сокращения числа граждан, соблюдающих режим самоизоляции, снятия ограничений на работу предприятий общепита, торговли и т.п., начала учебного года и окончания периода отпусков в России возможна вторая волна эпидемии COVID-19. Особенно с приходом холодов и началом сезона простудных заболеваний.

Был выполнен прогноз развития ситуации на конец лета и осенний период. Моделировалось два сценария - оптимистичный, предполагающий продолжение тренда на снижение прироста, и пессимистичный, предполагающий повышение темпов прироста к показателям, характерным для 2 фазы эпидемии. По результатам предсказаний на 30.11.2020 г. при реализации оптимистичного сценария ожидается около 1340 тысяч случаев инфицирования, из них около 267 тысяч тяжелых и примерно 22,5 тысячи летальных, согласно пессимистичному сценарию будет зарегистрировано более 1632 тысяч случаев заболевания, из них более 345 тысяч тяжелых и более 27 тысяч летальных.

\section{Материалы и методы}

\section{Данные.}

Для анализа были использованы данные Центра системологии и инженерных наук Университета Джонса Хопкинса, доступные для загрузки из официального репозитория https:/github.com/CSSEGISandData/COVID-19/. Использовались данные от компании Яндекс, доступные по ссылке https://datalens.yandex/covid19 - были использованы 3 доступные для загрузки таблицы - (1) с данными по количеству зарегистрированных случаев, выздоровлений и летальных исходов по дням в различных странах мира (по данным JHU); (2) с данными по количеству зарегистрированных случаев, выздоровлений и летальных исходов по дням в регионах Российской Федерации (по данным Роспотребнадзора) и (3) данные об изменении среднесуточного индекса самоизоляции (данные компании Яндекс). Также были использованы данные о численности населения в регионах России на начало 2020 года (данные Росстата), данные о численности населения в странах мира (JHU) и данные о количестве проведенных в регионах Российской Федерации лабораторных исследований и протестированных индивидуумов (Роспотребнадзор). 
Построение SIR-модели [3] проводилось с помощью библиотек numpy (v.1.18.1) [4] и scipy (v.1.5.1) [5] языка программирования Python (v.3.7). Решение системы обыкновенных дифференциальных уравнений SIR-модели проводилось с помощью метода Рунге-Кутта 5 порядка [6, 7], реализованного в библиотеке scipy. Оптимизация параметров модели проводилась с помощью метода Нелдера-Мида [8], реализованного в библиотеке scipy.

\section{Прогноз развития ситуации до конца осени.}

Расчет прогноза числа инфицированных новой коронавирусной инфекцией COVID-19 осуществлялся с использованием актуальных данных о количестве выявленных случаев заболевания новой коронавирусной инфекцией и летальных исходов в Российской Федерации. Показатель прироста рассчитан как отношение разницы кумулятивного числа больных на текущий и предыдущий день к общему числу больных на предыдущий день. Для каждого региона уровень смертности оценивался на основе последних актуальных данных; темп прироста для оптимистичного сценария определяется на основе анализа линейного тренда числа новых случаев за выбранный интервал времени (по умолчанию 2 недели). Для негативного сценария в качестве начального значения коэффициента прироста используется 1 + актуальное значение прироста, умноженное на повышающий коэффициент 1,3 - что в соответствии со сценарным прогнозом обозначает возвращение к фазе экспоненциального роста. В качестве условной даты начала второй волны нами было принято 14 сентября 2020 г.

\section{Список литературы}

1. Rahman B, Aziz IA, Khdhr FW \& Mahmood DFD. Preliminary estimation of the basic reproduction number of SARS-CoV-2 in the Middle East. [Preprint]. Bull World Health Organ. E-pub: 1 May 2020. doi: http://dx.doi.org/10.2471/BLT.20.262295.

2. https://www.who.int/docs/default-source/coronaviruse/risk-comms-updates/update-28covid-19-what-we-know-may-2020.pdf?sfvrsn=ed6e286c 2

3. Kermack WO, McKendrick AG. (1927). A Contribution to the Mathematical Theory of Epidemics. Proceedings of the Royal Society A. 115 (772): 700-721. doi:10.1098/rspa.1927.0118.

4. Virtanen P. et al. (2020) SciPy 1.0: Fundamental Algorithms for Scientific Computing in Python. Nature Methods, in press.

5. van der Walt S., Colbert C. and Varoquaux G. The NumPy Array: A Structure for Efficient Numerical Computation, Computing in Science \& Engineering, 13, 22-30 (2011), DOI:10.1109/MCSE.2011.37

6. J. R. Dormand, P. J. Prince, "A family of embedded Runge-Kutta formulae", Journal of Computational and Applied Mathematics, Vol. 6, No. 1, pp. 19-26, 1980.

7. L. W. Shampine, "Some Practical Runge-Kutta Formulas", Mathematics of Computation, Vol. 46, No. 173, pp. 135-150, 1986.

8. Nelder J.A. and Mead R. 1965. A Simplex Method for Function Minimization. The Computer Journal 7: 308-13. 